\title{
The progressive and ancestral traits of the secondary xylem within Magnolia clad - the early diverging lineage of flowering plants
}

\author{
Magdalena Marta Wróblewska* \\ Department of Developmental Plant Biology, Institute of Experimental Biology, University of Wrocław, Kanonia 6/8, 50-328 Wrocław, Poland
}

\begin{abstract}
The qualitative and quantitative studies, presented in this article, on wood anatomy of various species belonging to ancient Magnolia genus reveal new aspects of phylogenetic relationships between the species and show evolutionary trends, known to increase fitness of conductive tissues in angiosperms. They also provide new examples of phenotypic plasticity in plants.

The type of perforation plate in vessel members is one of the most relevant features for taxonomic studies. In Magnolia, until now, two types of perforation plates have been reported: the conservative, scalariform and the specialized, simple one.

In this paper, are presented some findings, new to magnolia wood science, like exclusively simple perforation plates in some species or mixed perforation plates - simple and scalariform in one vessel member. Intravascular pitting is another taxonomically important trait of vascular tissue. Interesting transient states between different patterns of pitting in one cell only have been found. This proves great flexibility of mechanisms, which elaborate cell wall structure in maturing tracheary element. The comparison of this data with phylogenetic trees, based on the fossil records and plastid gene expression, clearly shows that there is a link between the type of perforation plate and the degree of evolutionary specialization within Magnolia genus.
\end{abstract}

Keywords: Magnolia; basal angiosperms; secondary xylem; perforation plate

\section{Introduction}

Magnolias are classified as the magnoliids group that represent 3\% of all angiosperms species. They diverged from the angiosperm ancestral line before the separation of the two major evolutionary lines of monocotyledones and dicotyledones [1]. They have both the ancestral features and those depicting specialization, therefore they lately became intensively studied. Morphological and anatomical studies gave the evidence for ancestral character and early rise of this group taking into account the number of original features such as undifferentiated perianth, numerous spirally arranged generative parts, construction of the pollen and presence of the oil cells [2-5].

To the Magnoliales order belongs family Magnoliaceae. First detailed classification of this family, created by James E. Dandy, was based on the flower and fruit morphology. This classification was widely accepted over the years, just with minor modifications, until Noteboom's study. Noteboom has reorganized the taxonomy taking into account "tricks of nature", such as homoplasies (the same features of different origin) in fruit structure [6,7]. Subgenera of magnolias are

\footnotetext{
*Email: magdalena.turczyn@gmail.com
}

Handling Editor: Beata Zagórska-Marek classified based on the morphology of flowers on flowering time and structure of leaves. With the development of DNA sequencing a new method became available and the $n d h F$ chloroplast gene was first to be examined in Magnoliaceae. The results proved polyphyletic origin of Magnolia and established new connections between minor sections [8]. Molecular data confirmed also early origin of magnoliids [9].

In addition to flower structure the taxonomists use wood anatomy in various classifications systems and anatomical keys. The wood (secondary xylem) is a secondary conducting tissue in perennial woody plants, which develops due to activity of cambium - secondary meristem. Vessels, present only in angiosperm wood, are most significant elements with traits of taxonomic value. The units of the vessel, the cells called vessel members, function as dead elements. They are produced by cambial fusiform initials through their periclinal divisions. Vessel elements differentiate increasing in diameter, thus their length is more or less the same as the length of producing them cambial initials. Their length's mean value increases in early ontogeny of a tree (in accordance with Sanio rule for non-storied cambium). They are composed of the cell wall only and are interconnected vertically by perforation plates to form a pipe conducting water. The cell wall pattern is characteristic and can be diverse, its formation is driven by the expression of specific genes involved in biosynthesis of polysaccharides, lignins, 
proteins etc. [10]. The development of a perforation plate is especially well-studied process. The perforation is created by the primary wall enzymatic breakdown on the border between the two adjacent elements, in the areas not covered by the secondary cell wall. Important role in this process is played by cellulase, which degrades some cellulose microfibrils. The remaining fibrils are either carried away by a transpiration stream $[11,12]$ or some of them stay forming thread-like structures in a plate, this feature is found in less specialized vessel members [13]. The perforation plate can be set obliquely or transversely, with regard to the axis of the vessel. The plate may have only one large opening and then it is called a simple perforation plate (Fig. 1a) or several small perforations. Their arrangement allows distinguishing three basic types of plates: scalariform (Fig. 1b), which is composed of flattened openings arranged parallel to each other, reticulate (Fig. 1c) where the openings form a network and foraminate (Fig. 1d) with the series of circular openings. In the course of evolution the perforation plates specialized from scalariform to the simple plate [14], evident is also gradual shortening of vessel members [13].

Vessels contact with other, adjacent xylem elements through the pits situated on the lateral walls. Pits may form defined patterns. When they are horizontally elongated and form a ladder-like vertical series with the lateral length of each pit comparable to the vessel width, their arrangement is called scalariform pitting (Fig. 1a). In transitional pitting (Fig. 1b) some pits are shorter, they occur in laterally adjacent groups of 2-3 pits and these groups alternate longitudinally with long pits. Pseudoscalariform pattern (Fig. 1b) occurs when the shorter pits appear in between two longer ones, disrupting the ladder-like structure. The lateral series of round or elliptical in outline pits are present in a pattern of opposite pitting (Fig. 1c). The pits are arranged on the vessel wall in horizontal and vertical rows. In another variant of this pattern the pits in consecutive horizontal rows are laterally shifted, which leads to formation of diagonal rows instead of vertical (Fig. 1d). This, most common in dicotyledonous plants type of pitting, is called an alternate pattern [15]. The pit packing in alternate pattern is much more efficient than in opposite one, accommodating more pits on the wall surface of the same size. This naturally increases the lateral transport of water and thus should be treated as an advantageous, evolutionary novelty.

Magnolia's wood is generally described as diffuse - porous, where vessels are of the same diameter and evenly distributed within a growth ring, either solitary or in short radial multiples containing 3-4 adjacent vessels. Vessels in such ancient plants should be considered as a progressive trait, because there are some magnoliids like Trochodendron and Tetracentron, which are completely vesselless. Their wood resembles more wood of gymnosperms than of flowering plants. In Magnolia wood the annual rings are distinct and limited by the marginal band of tracheids and/or parenchyma cells. Rays are hetero- and homocellular. Vessel members in Magnolia have spiral thickenings on the walls $[16,17]$. Wood features, which are used to distinguish the individual species within Magnoliaceae are mainly the vessel member traits, like the type of perforation plate and pattern of pitting. Therefore these elements are of special interest. In Magnolia the presence of both simple and scalariform type of plate has been described. The species with exclusively simple perforation plates are for example: Magnolia acuminata (L.) L., M. stellata (Sieb. \& Zucc.) Maxim., M. obovata Thumb. (previous name: M. hypoleuca), M. officinalis Rehd. \& Wilson, M. kobus DC, M. liliiflora Desr. [prev.: M. quinquepeta
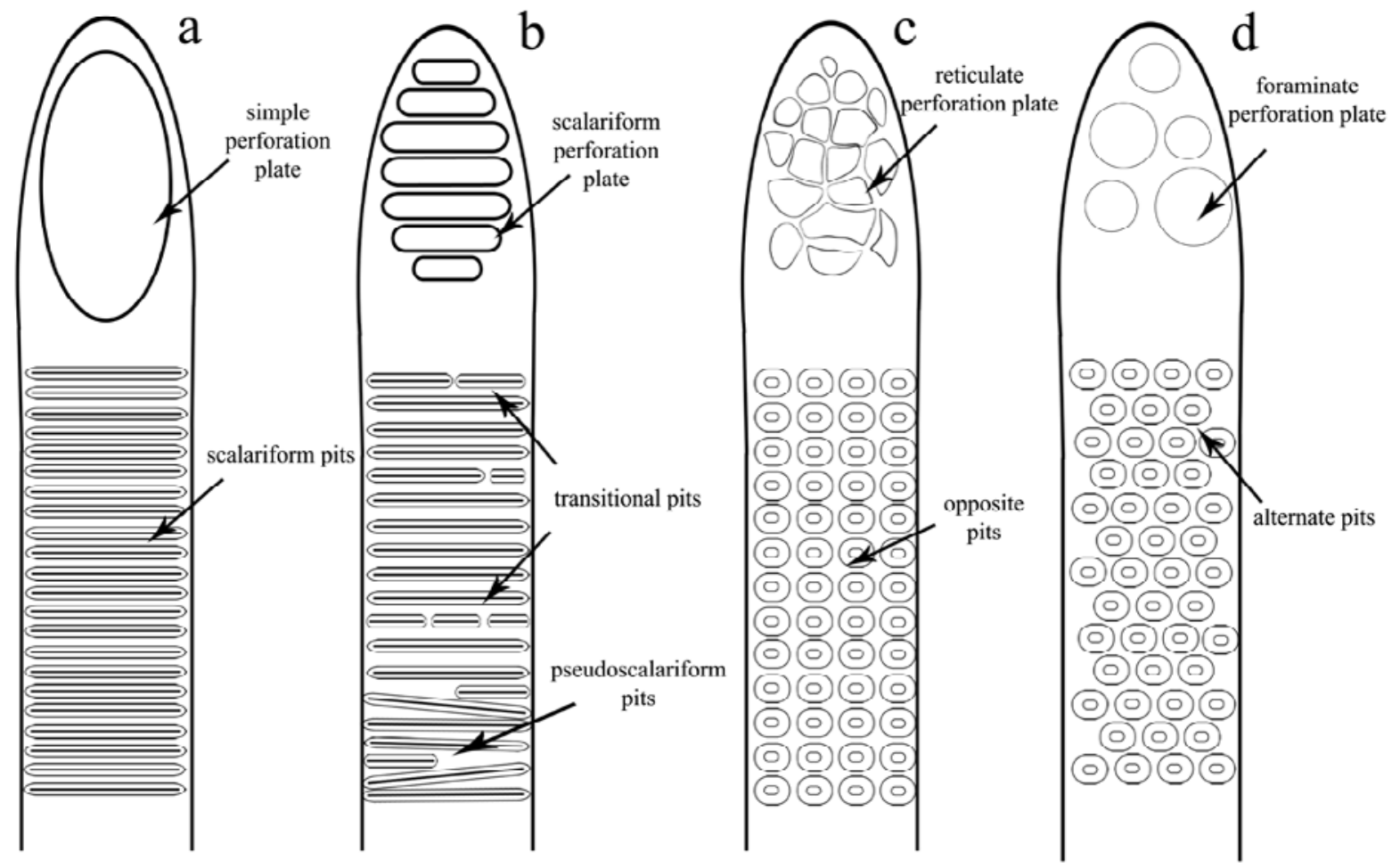

Fig. 1 The morphology of vessel members: the types of perforation plates: simple (a), scalariform (b), reticulate (c), foraminate (d) and different patterns of pitting: scalariform (a), transitional (b), pseudoscalariform (b), opposite (c), alternate (d). 
(Buchoz) Dandy], the species with scalariform perforations are M. sieboldii K. Koch, M. cylindrica Wilson, M. tripetala (L.) L. Interestingly, there are some species with both types of perforation plates, like M· denudata Desr. [prev.: M. heptapeta (Buchoz) Dandy] [18].

In this paper it is shown that variation in wood architecture described in the literature occurs in magnolias growing in Poland in humid continental climate (Köppen-Geiger classification) [19] and that quantifying these variations, provides new information on their taxonomic significance. Interesting modifications in the perforation plate morphology have been noted as an example of flexibility in this group of flowering plants. Since the simple perforation plate is considered to be a progressive and characteristic feature of phylogenetically younger species, its presence was examined more closely and showed the connection between the timing of species emergence in the tree of life and its wood micromorphology. The results were compared with widely available information on magnolias geographic distribution, fossil records and their plastid and nuclear genes sequences analysis.

\section{Material and methods}

Wood samples were collected from mature branches of trees and shrubs. Into the study only solidly confirmed species were included, excluding hybrids, varieties and trees, which were decoratively trimmed. All examined individuals, representing the Magnolia species, grow in the Botanical Garden of the University of Wrocław (Wrocław, Poland) and in WULS-SGGW Arboretum in Rogów (Rogów, Poland; Tab. 1).

Tab. 1 Species of the Magnolia from WULS-SGGW Arboretum in Rogów (Rogów, Poland) and Botanical Garden of the University of Wrocław (Wrocław, Poland) used in the present study.

\begin{tabular}{llll}
\hline Section & Species & $\begin{array}{l}\text { Number of } \\
\text { examined } \\
\text { trees }\end{array}$ & $\begin{array}{l}\text { Age of } \\
\text { branches for } \\
\text { each tree }\end{array}$ \\
\hline Yulania & Magnolia acuminata & $4(2)$ & $10 / 9 / 9 / 8$ \\
& Magnolia cylindrica & 1 & 6 \\
& Magnolia denudata & $2(1)$ & $8 / 9$ \\
& Magnolia kobus & $3(1)$ & $9 / 8 / 7$ \\
Rytidospermum & Magnolia liliflora & $4(1)$ & $9 / 8 / 8 / 7$ \\
& Magnolia salicifolia & $3(1)$ & $9 / 9 / 9$ \\
& Magnolia stellata & $2(1)$ & $10 / 8$ \\
& Magnolia officinalis & $3(1)$ & $9 / 8 / 7$ \\
& Magnolia sieboldii & $4(2)$ & $9 / 9 / 8 / 8$ \\
& Magnolia tripetala & $3(1)$ & $9 / 8 / 7$ \\
& Magnolia wilsonii & 2 & $10 / 9$ \\
& Magnolia virginiana & 2 & $8 / 8$ \\
\hline
\end{tabular}

In parentheses is given the number of individuals coming from the Botanical Garden of the University of Wrocław.
Wood anatomy was analyzed with use of two techniques: wood sections and macerates. Initially wood discs from 6-10 year old branches were boiled in the distilled water with glycerol for 30 hours to soften the material. Then, out of pretreated wood blocks, $20 \mu \mathrm{m}$ thick sections (transverse, radial and tangential) were cut using a sliding microtome Leica S14 2000R (Leica Instruments, GmbH, Germany). Permanent microscope slides were prepared as follows: the sections mounted on the slides had been bleached with use of sodium hypochlorite $(\mathrm{NaClO})$, stained with Malachite Green and dehydrated with ethanol and isopropanol series. Afterwards they were embedded in Euparal [20,21].

The wood macerates were prepared from the outermost growth ring. Each wood sample was treated overnight with acetic acid and then boiled in 3\% hydrogen peroxide for 6 hours or until visible separation of cells had occurred. Some samples were also stained with alcian blue for better contrast $[20,21]$. The pictures were taken with Olympus BX50 Microscope, Olympus Camera DP71 and Cell B Software (Olympus Optical Co., Warsaw, Poland).

To compare the frequencies of perforation plate types in Magnolia, 120 vessel members for each species were analyzed. 30 measurements of the length and width from vessel elements for 13 species, separately for each individual, were taken using Cell B Software Arbitrary Measure Tool. For these species in which more than one type of perforation plate occurred, 30 measurements were taken separately for the cells with exclusively scalariform, simple and mixed perforation plates. To correlate different features we performed statistical tests. Normal distribution was analyzed with the Shapiro-Wilk test and the comparisons of mean vessel length and diameter between Magnolia species with the Welch Two Sample $t$-test. Statistical data were obtained with the R program [22].

\section{Results}

\section{General wood morphology}

Blocks of wood, collected from mature branches, were analyzed in three planes: transverse, radial and tangential to show all the anatomical features of a secondary xylem. The anatomical features common for all Magnolia species, studied here, are listed as follows. The wood was diffuseporous. Vessels of the same growth ring had at the average the same diameter and were arranged either solitary or in 2-4 radial multiples (Fig. 2a), rarely in clusters. The terminal layer (Fig. 2b) was distinct, formed by flattened tracheids, 3-4 in each row. Rays were homogeneous and usually 1-4 seriate (Fig. $2 c, d$ ). In the vessels both simple and scalariform perforation plates and various patterns of pits were observed (Fig. 2c). Tertiary thickenings, very thin, were present in some vessel elements. Better description of the morphology of a single and entire vessel member was possible while observing macerates rather than microtome sections.

\section{Perforation plates}

Perforation plates were examined qualitatively and quantitatively in the wood of 13 Magnolia species with use of macerates. Three types of vessel elements with different 

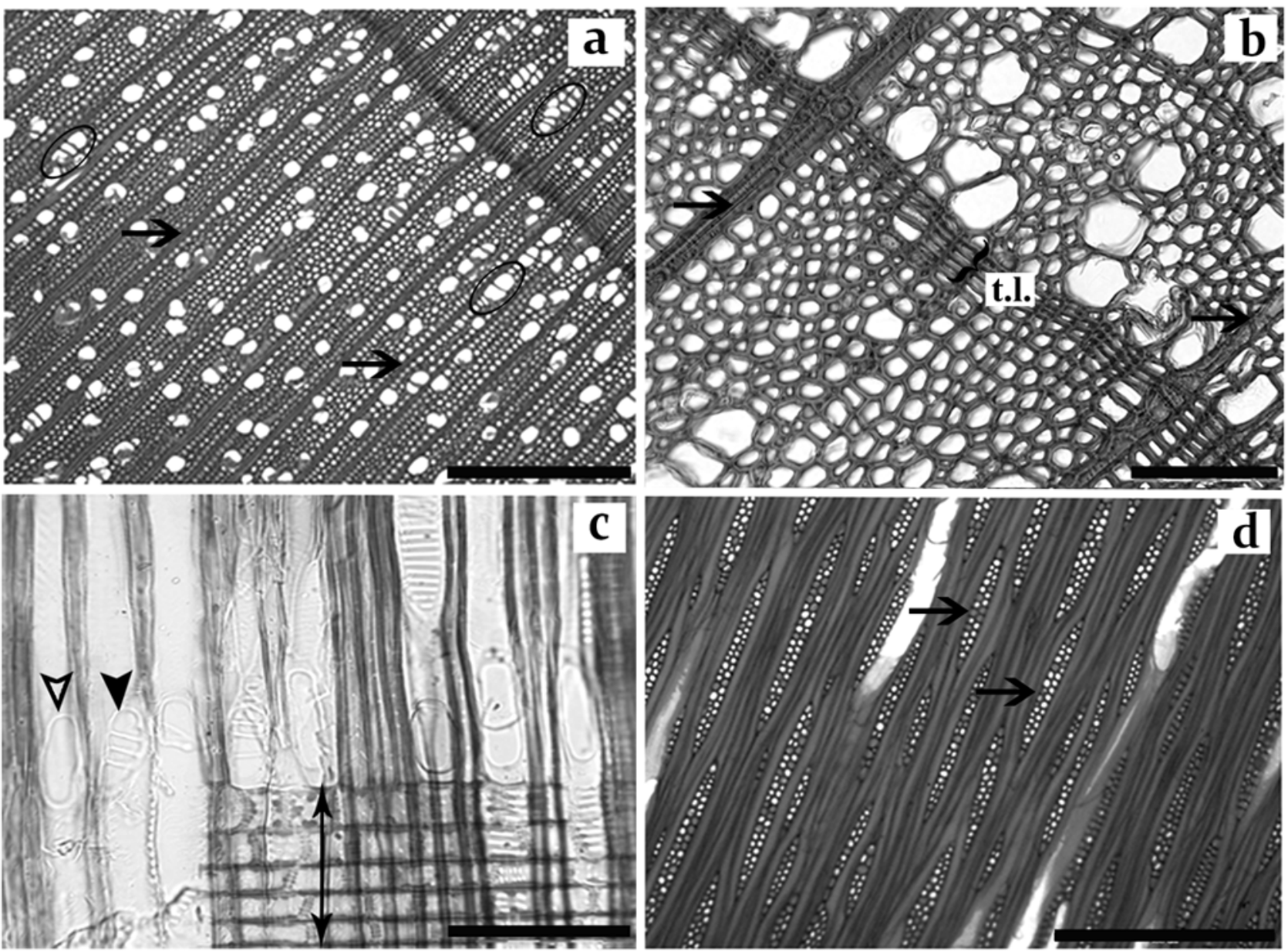

Fig. 2 Details of Magnolia wood anatomy. Diffuse-porous wood of M. sieboldii on transverse sections (a,b), the wood rays indicated by arrows, vessels in radial multiples marked with the circles (a); flattened tracheids in terminal layer (t.l.; b); simple (white arrowhead) and scalariform (black arrowhead) perforation plates in vessels and part of homogeneous ray marked with double arrow on the radial section of $M$. stellata wood (c); 2-3- seriate rays on tangential section of $M$. stellata wood - pointed by arrows (d). Scale bars: $500 \mu \mathrm{m}$ (a); $100 \mu \mathrm{m}(\mathbf{b}, \mathbf{c}) ; 200 \mu \mathrm{m}(\mathbf{d})$.

perforation plates were documented: exclusively scalariform, exclusively simple or mixed, with two different perforation plates at the opposite ends of one vessel member. Exclusively scalariform perforation plates were characteristic of four examined species: M. virginiana (Fig. 3a), M. wilsonii (Fig. 3b), M. sieboldii (Fig. 3c) and M. tripetala (Fig. 3d). Vessel members with exclusively simple perforation plates were observed in M. acuminata, M. salicifolia and M. kobus (Fig. 3e-g, respectively). In the species: M. obovata (Fig. 4a), M. liliiflora (Fig. 4b), M. cylindrica (Fig. 4e), M. officinalis (Fig. 4f), M. stellata (Fig. 4h), M. denudata (Fig. 4k) vessel members with both types of perforation plate in one cell were encountered among others. Except for the two groups of species with exclusively simple or scalariform plates, the frequency of different types of plates, for the specimens analyzed in this paper, was species specific. In M. obovata (Fig. 4a), M. stellata (Fig. 4h,i), M. officinalis (Fig. 4f,g), M. denudata (Fig. 4j,k) only simple and mixed perforation plates occurred, whereas M. liliiflora (Fig. 4b,c) and M. cylindrica (Fig. $4 \mathrm{~d}, \mathrm{e}$ ) had all three types of vessel elements with simple, scalariform and mixed perforation plates. The frequency of specific vessel member types is shown in Tab. 2 .
Results (the ratio of plate types) for individuals from one species analyzed from two places were the same. Within the species that have simple and mixed perforation plates the greater percentage of cells had simple type of plate, more than $70 \%$. The same was true for M. liliiflora, which has all three types of plates. In this species the vessel members with mixed and exclusively scalariform plates together were still in minority, of $30 \%$ only. However, in M. cylindrica the ratio of simple, mixed and scalariform types of plates was as 1:1:2. Spiral thickenings of the vessel member wall were visible in M. cylindrica (Fig. 4d,e), M. stellata, M. denudata (Fig. 4i,k; respectively)

Vessel members with exclusively scalariform plates - on both ends of one cell, had at the average 12 bars in the plate. The highest number of bars (20) was found in M. sieboldii and in M. wilsonii. Species with mixed perforation plates usually had plates with only 1-4 bars. In M. sieboldii, M. tripetala and M. wilsonii the modification of plate structure was found, such as bifurcations of the bars (Fig. 5a). Usually there was only one bifurcation per plate but there were cases where even 3 bifurcating bars were observed. Other interesting aberrations resulted from the evidently 


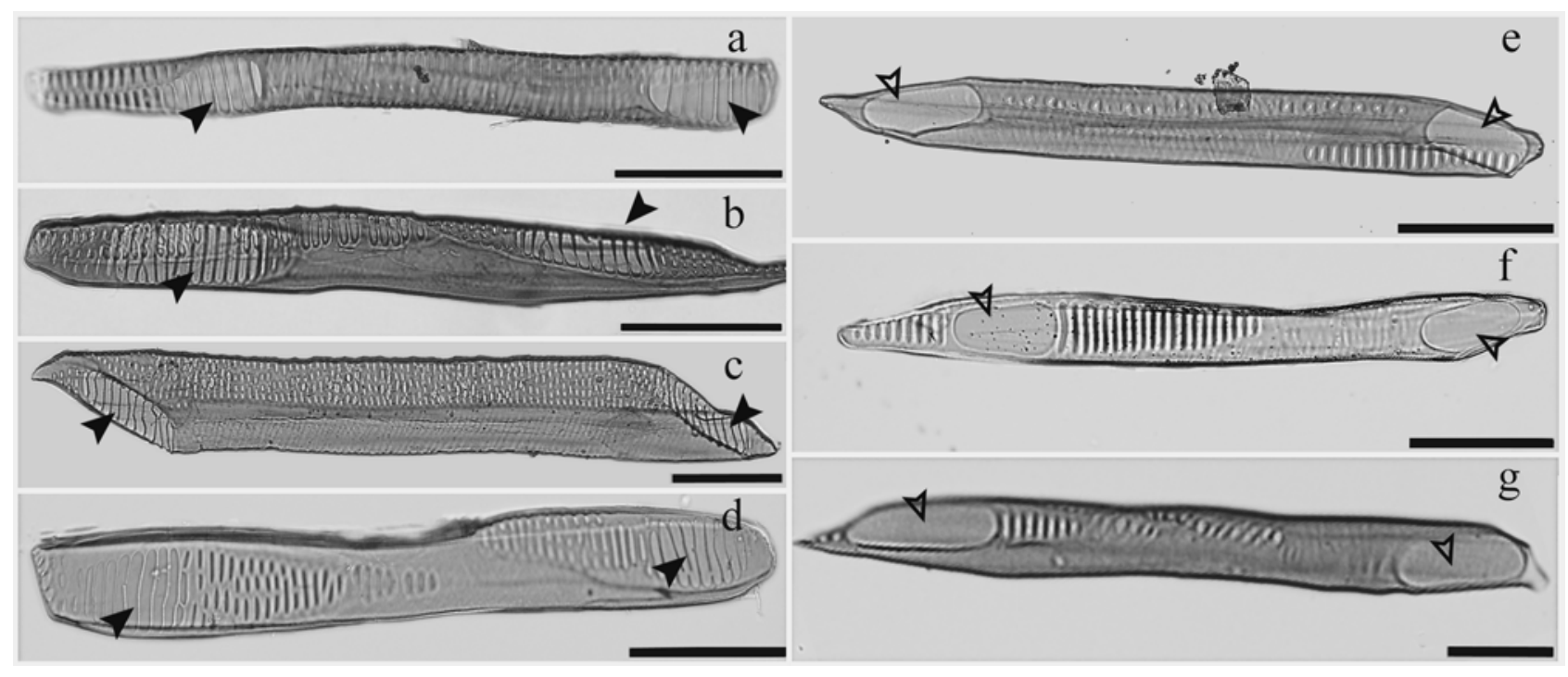

Fig. 3 The Magnolia species with exclusively scalariform perforation plates (a-d; pointed by black arrowheads) and with exclusively simple perforation plates (e-g; pointed by white arrowheads). M. virginiana (a); M. wilsonii (b); M. sieboldii (c); M. tripetala (d); M. acuminata (e); M. salicifolia (f); M. kobus (g). Scale bar: $100 \mu \mathrm{m}$.

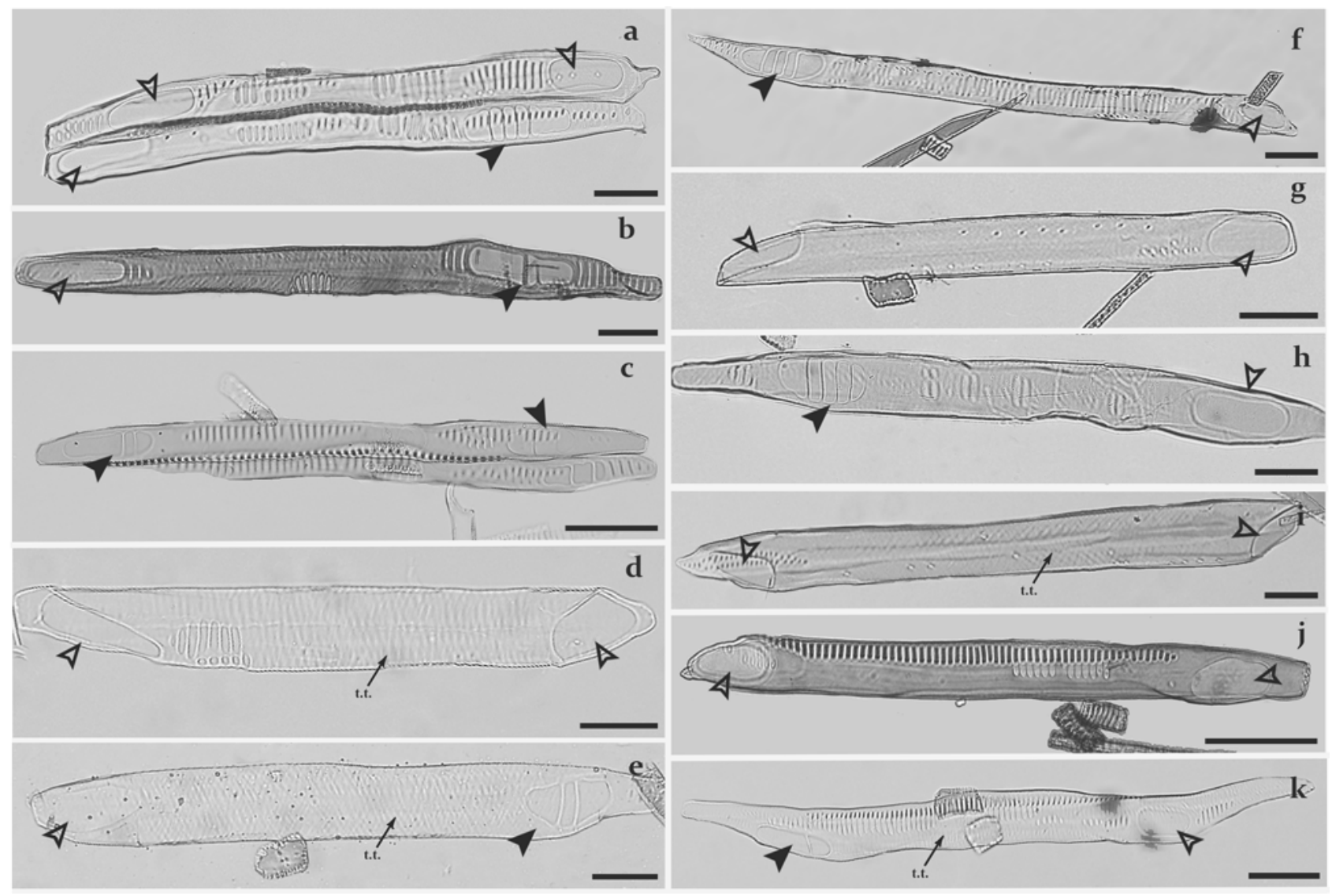

Fig. 4 The Magnolia species with more than one type of perforation plate. a M. obovata - two vessel members: one with exclusively simple perforation plates (above), the second with mixed perforation plates (below). $\mathbf{b}$ M. liliiflora - vessel member with two types of perforation plates. c $M$. liliiflora - vessel member with scalariform perforation plates having two bars only. d,e $M$. cylindrica - vessel member with only simple perforation plates (d) and mixed type of plate (e). f,g $\mathbf{M}$. officinalis - vessel member with mixed perforation plates (f) and with exclusively simple plates (g). h,i M. stellata - vessel member with mixed perforation plates (h) and with two simple perforation plates $(\mathbf{i})$. $\mathbf{j}, \mathbf{k} M$. denudata - vessel member with exclusively simple perforation plate $(\mathbf{j})$ and mixed perforation plates $(\mathbf{k})$. In vessel members delicate tertiary thickenings (t.t.) of the cell wall are visible - pointed by arrows (d,e,g,i); the scalariform perforation plates pointed by black arrowheads and simple by white arrowheads. Scale bar: $100 \mu \mathrm{m}$. 
Tab. 2 Frequency of various perforation plate types present in analyzed Magnolia species.

\begin{tabular}{lccc} 
& \multicolumn{3}{c}{ Perforation plate } \\
\cline { 2 - 4 } Species* $^{*}$ Simple & Scalariform & Mixed \\
\hline Magnolia sieboldii & ---- & $100 \%$ & ---- \\
Magnolia tripetala & --- & $100 \%$ & ---- \\
Magnolia virginiana & ---- & $100 \%$ & ---- \\
Magnolia wilsonii & ---- & $100 \%$ & ---- \\
Magnolia acuminata & $100 \%$ & ---- & ---- \\
Magnolia kobus & $100 \%$ & ---- & ---- \\
Magnolia salicifolia & $100 \%$ & --- & --- \\
Magnolia denudata & $86 \%$ & --- & $13 \%$ \\
Magnolia obovata & $90 \%$ & ---- & $10 \%$ \\
Magnolia officinalis & $74 \%$ & ---- & $26 \%$ \\
Magnolia stellata & $85 \%$ & ---- & $15 \%$ \\
Magnolia cylindrica & $24 \%$ & $51 \%$ & $25 \%$ \\
Magnolia liliiflora & $72 \%$ & $10 \%$ & $18 \%$ \\
\hline
\end{tabular}

* Species are listed in alphabetical order within each group having specific pattern of perforation plate types.

imperfect plate formation in the maturing vessel member. In $M$. obovata the structures resembling very short bars in otherwise simple perforation plates were noted (Fig. 5b). In M. denudata (Fig. 5c) partially developed bars occurred: the plate structure where a single bar ended in the middle of a plate was observed. This was in a sense a negative image of the bifurcated bar - a bifurcated perforation. In M. salicifolia two simple perforation plates on one side of a cell have been found (Fig. 5d).

\section{Intravascular pitting}

The scalariform type of intravascular pitting (Fig. 6a) present on the lateral cell walls of vessel members was next characteristic feature for all examined species. In some cases, like in M. liliiflora, a continuous transitions between three types of pitting was observed: reduction of one of the pits lateral dimension, resulted in a change from scalariform to transitional pattern and then further to opposite one
(Fig. 6b). In M. tripetala the oval pits of similar dimensions in the opposite arrangement were present. In this case instead of a single, laterally elongated pit two, three or even four shorter ones occurred in one row (Fig. 6c). Additionally, in $M$. liliiflora and $M$. denudata pseudoscalariform pits had been found (Fig. 6d). In this pattern some pits were shorter than others and not arranged in the lateral series. They looked like wedges pushing apart neighboring lateral pits.

\section{Vessel cells dimensions}

Measurements of the lengths and widths of vessel members in all examined species did not reveal significant intraspecific differences between individuals. There were, however, interesting differences among the species (Fig. 7). The longest and narrowest vessel elements were documented for Magnolia denudata in the category of mixed-plate cells, and the shortest (but not the narrowest) in M. virginiana where the plates were exclusively scalariform. The highest diameter was scored for M. acuminata having exclusively simple plates. The statistical tests were performed to evaluate the significance of scored dimensions. There was no correlation within the species between vessel member dimensions and the perforation plate types. The only statistically significant differences in vessel cell lengths (upper part of a plot in the Fig. 7), occurred between M. virginiana and the group with exclusively scalariform perforation plates, and also between $M$. salicifolia and the species with exclusively simple perforation plates.

Considering vessel widths, three groups of statistically similar species can be indicated. The first one consists of the species with scalariform perforation plate: M. liliiflora, M. sieboldii, M. virginiana and $M$. wilsonii, to the second, with mixed perforation plate, M. cylindrica and M. liliiflora belong and to the third, with simple perforation plate, $M$. $c y$ lindrica, $M$. denudata, M. kobus, M. liliiflora and M. obovata.

\section{Discussion}

The Magnoliaceae family is distributed natively in temperate, subtropical and tropical regions of northern part of South America, Central America and North America to the
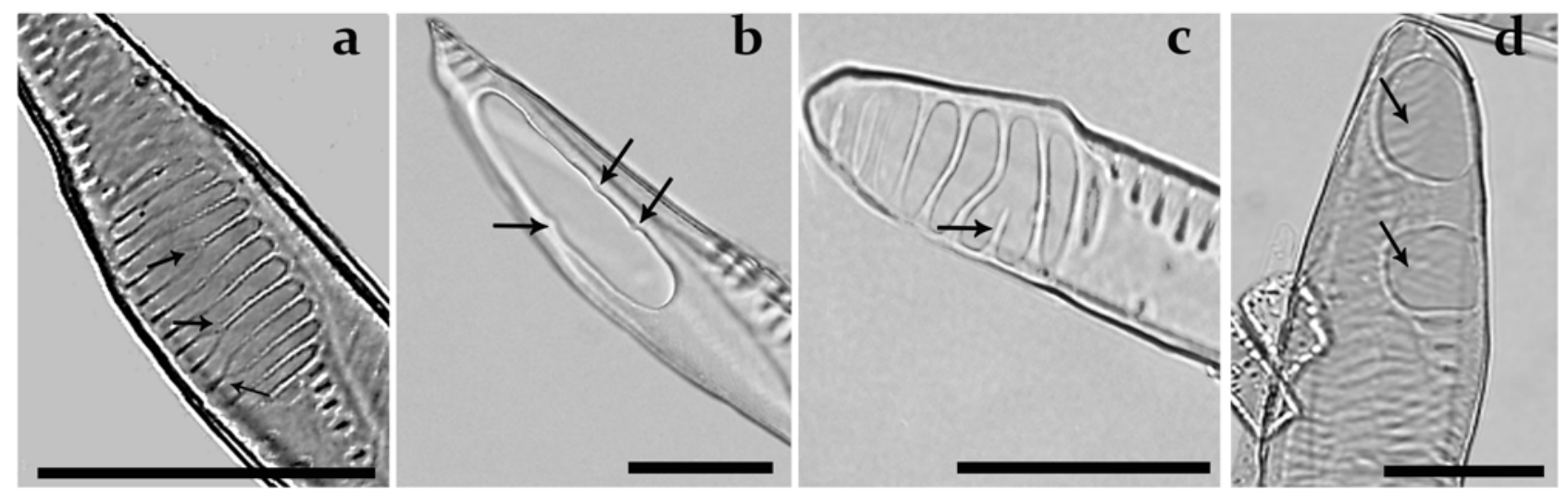

Fig. 5 Aberrant perforation plates. a Three bar bifurcations in one plate (pointed by arrows) in M. sieboldii. b The structures resembling developing but "unfinished" bars (indicated by arrows) in otherwise simple perforation plate of M. obovata. c A scalariform perforation plate with partially developed bar (see arrow) in M. denudata. $\mathbf{d}$ Tip of the vessel element with two perforation plates formed close by in M. salicifolia. Scale bar: $100 \mu \mathrm{m}$. 


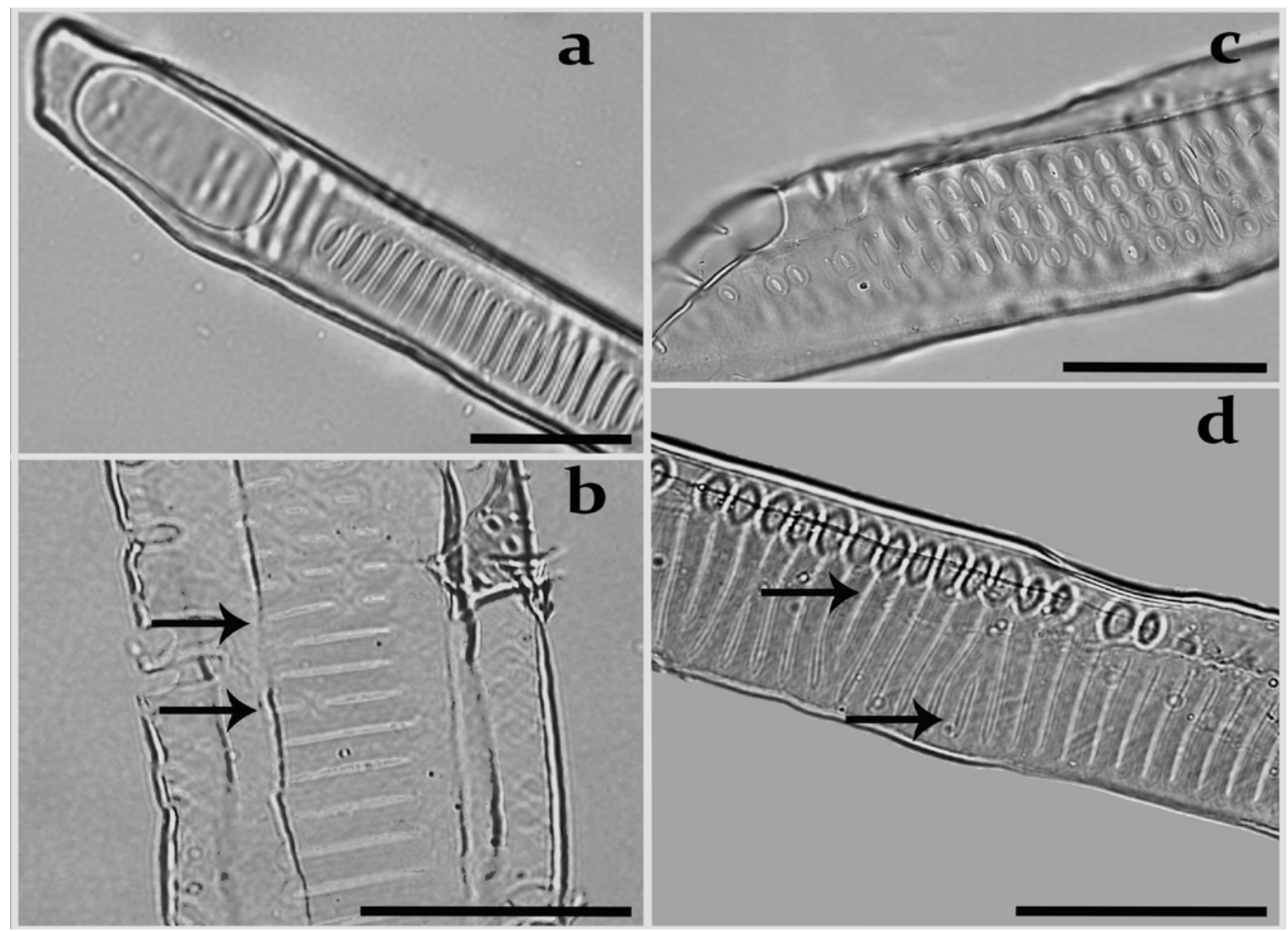

Fig. 6 Patterns of lateral cell wall pitting in vessel members. a Progressively simple perforation plate and ancestral scalariform pitting of the cell wall in M. acuminata. b Transitional pitting in the area denoted by arrows in M. liliiflora. c Opposite pits in M. tripetala. $\mathrm{d}$ Pseudoscalariform pitting in $M$. denudata, arrows point out the sites of shorter pits insertion. Scale bar: $50 \mu \mathrm{m}$.

Great Lakes and southern and eastern Asia [23]. Taxonomists and evolutionists based their research on magnolia wood considering only the genets (individuals) from these regions. In Poland, like elsewhere in Europe, magnolias extinct due to the Pleistocene glaciations, were reintroduced, thus their properties as of plants growing in different than native climatic conditions seemed to be of interest, especially in light of arguments for environmental impact on wood anatomy provided by "ecological wood anatomy" [24]. The Magnolia wood analyzed in this study was sampled from the trees growing in Poland and apparently was not much different from that described in literature with the exceptions discussed below.

The material used in this study was the wood from Magnolia branches. These parts of a tree or a shrub are more accessible than the main trunk and no specific drills are necessary. Therefore, in this research the main attention has been focused on that type of plant material, which is readily available for taxonomical analyzes. It is possible that besides the potential impact of environmental cues this was the reason why some characteristics of this wood were different from the literature data based on the wood sampled from the main stem.

Significant differences were found in the perforation plates. The data presented in the literature depicts the species like $M$. officinalis, M. liliiflora as those with exclusively simple perforation plates [18]. Data presented in these paper show that, beside simple plates also have mixed perforation plates. Furthermore, in M. liliiflora the cells with exclusively scalariform perforation plates were found. Magnolia obovata is described by Chen group as a species with exclusively simple perforation plates and by the InsideWood Working Group (IWG) as a species with simple and scalariform perforation plates $[25,26]$. In this study mostly simple but also mixed perforation plates have been shown. Magnolia cylindrica described in the literature as the species with exclusively scalariform type [18] in this study showed the vessel elements with all possible types of perforation plates: exclusively simple, scalariform and mixed. For M. denudata the presence of exclusively scalariform perforation plates reported by Chen group or simple and scalariform perforation plates described by IWG was not confirmed. The majority of vessel members in this species had simple or mixed perforation plates. Except for above differences the results of analyses performed on stem wood, available in the literature, are similar to those obtained in this study for the wood sampled from branches.

In three species with exclusive scalariform perforation plates: M. sieboldii, M. tripetala and M. wilsonii a feature known in literature as forking bars [27] was noticed. This 


\section{Vessel cells dimensions}

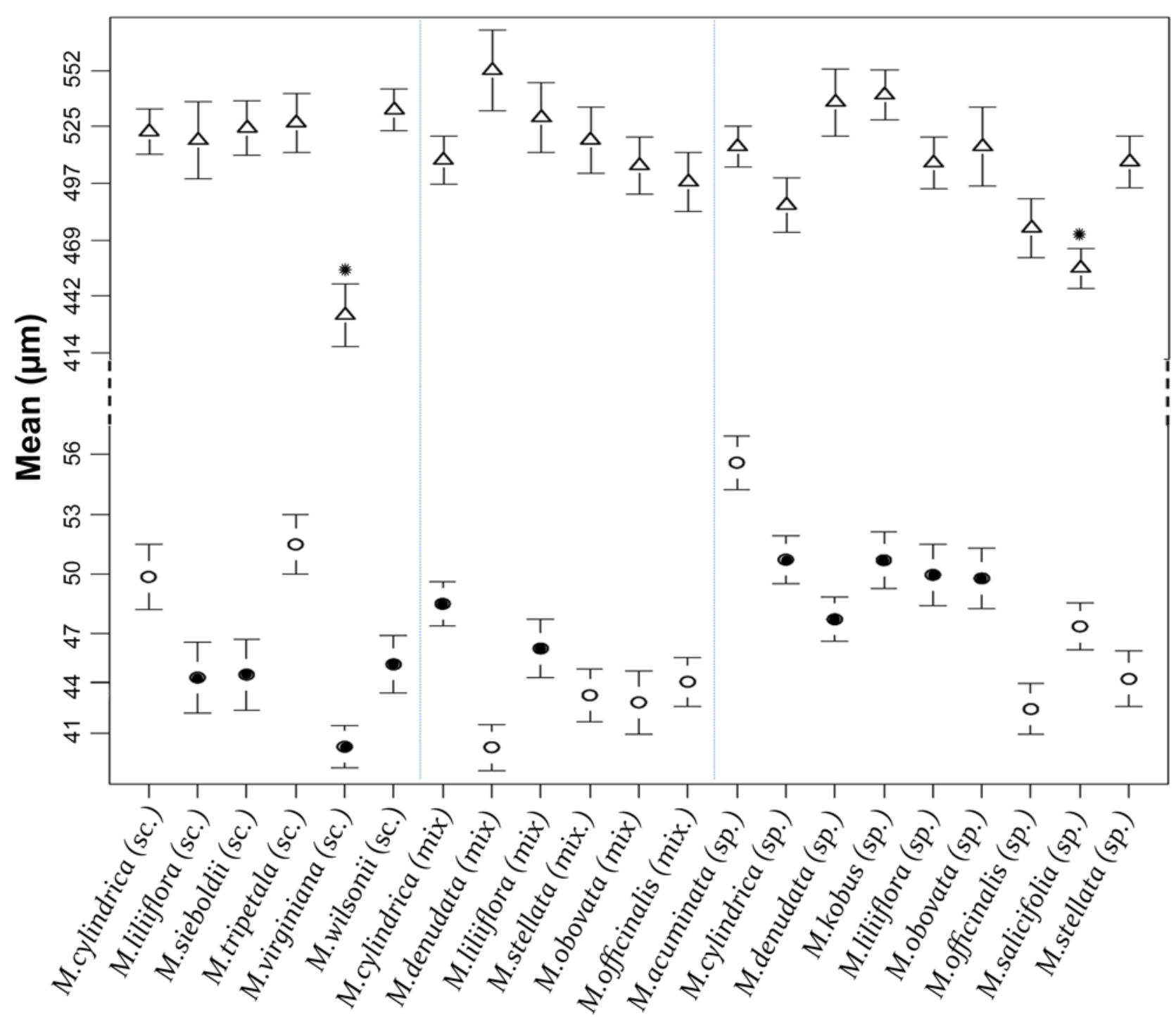

Fig. 7 Vessel cells dimensions. Mean $(\mu \mathrm{m}) \pm$ std. err. of the vessel member length (upper part of the plot) and width (lower part of the plot) shown in groups of magnolia species distinguished by perforation plates, listed in alphabetical order within each group. (sc.) - vessel cells with exclusively scalariform plate; (mix.) - cells with mixed perforation plates; (sp.) - cells with exclusively simple perforation plates. Asterisks in the upper part of the plot show the species with significant differences in cells length and black dots in lower part indicate the species with no significant differences between mean values of the width.

phenomenon occurs in many angiosperms and sometimes it leads to the identification of a plate as a scalariform type, especially when most of the bars in one plate is forked, like for example in Miodocarpus fraxinifolius [28]. In this study maximum three forkes per one plate were documented (Fig. 5a). Interestingly, bifurcations occurred often on both perforation plates of the vessel.

In the literature there is a variety of molecular and fossil data important and useful in reconstructing magnolias evolution $[8,29,30]$. The researchers speculate that the evolutionary trend in wood evolution leads from scalariform perforation plate to the simple one [31]. Therefore, the occurrence of plate types within analyzed Magnolia species was correlated in this study with the time of species divergence.
New morphological data were compared here with the information from the cladograms created by independent groups $[8,29,30]$. The combined cladogram (Fig. 8) allowed concluding that the time of species disjunction is indeed reflected in the vessel morphology. Younger species like M. acuminata have exclusively simple perforation plate while the older ones, like M. virginiana, exclusively scalariform. The results of comparison mentioned above are supported also by literature data. Scalariform perforation plates were reported in Magnolia species (prev. Talauma genus) from Borneo in tropical Asia. This clad is known as ancestral lineage within Magnoliaceae family [32]. Azuma group has noticed that there is a need to compare once again the morphological characters between $M$. tripetala and section 

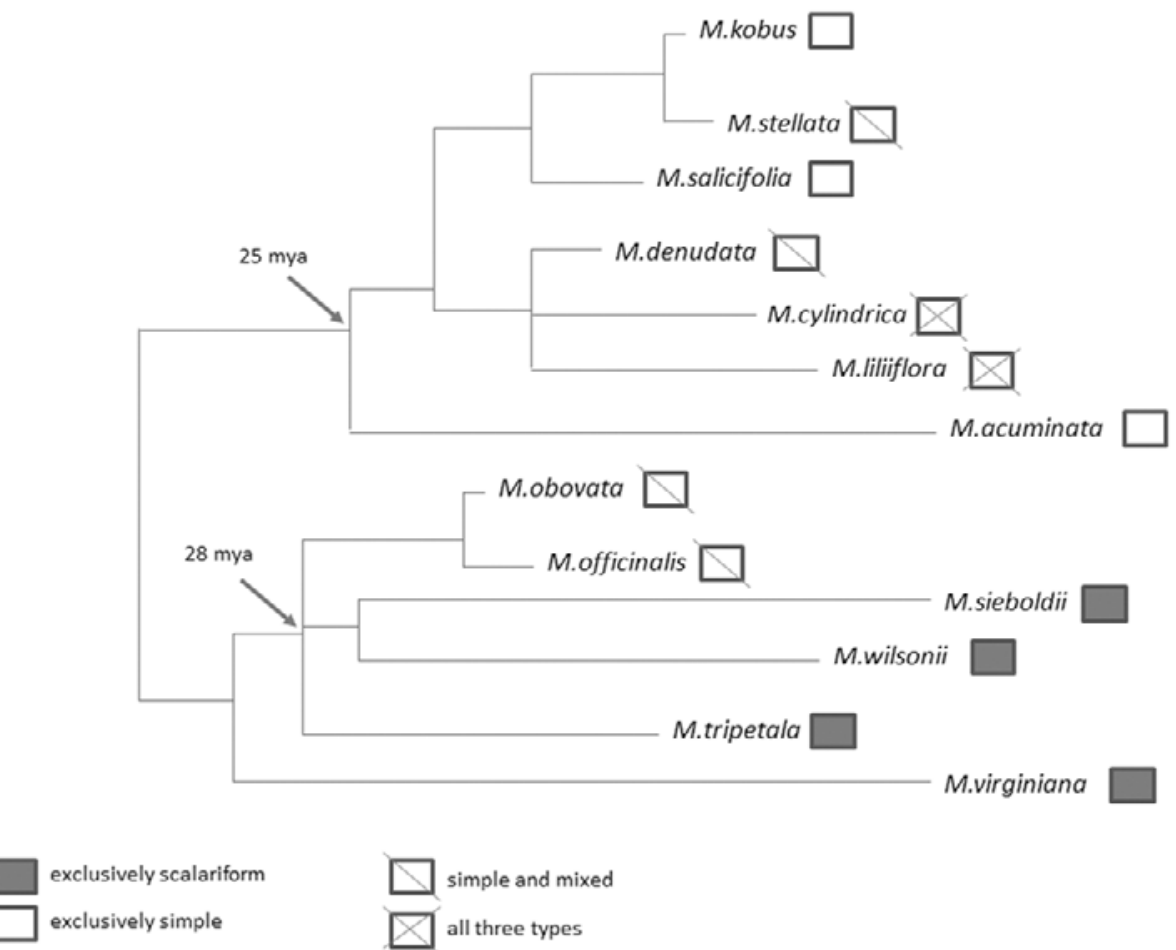

Fig. 8 Combined cladogram of our data on the types of perforation plates with the data known from literature on magnolia species divergence (Azuma et al. [29], modified; Kim et al. [8], modified; Nie et al. [30], modified). Arrows indicate estimated time of separation given in million years (mya). Squares show the type of perforation plate occurring in the species.

Oyama, which includes M. sieboldii and M. wilsonii to confirm or disprove the phylogenetic relationship based on molecular data. The presence of exclusively scalariform perforation plate in both section Oyama and Magnolia tripetala found in this study could be the missing morphological feature sustaining the molecular relationships. This close association is in opposition to M. virginiana (section Magnolia) in which also exclusively scalariform perforation plates occur but the statistical analyses suggest that this species has shorter and narrower vessel members. Evolutionary trends are shortening of tracheary elements of cambial origin and changing the ancestral scalariform perforation plates to the simple ones. Magnolia virginiana with its short vessel members and exclusively scalariform perforation plates is an example of heterobatmy - coexistence of progressive and ancestral traits in the same organism in the result of different rate of their evolutionary specialization. Opposite condition seems to occur in $M$. denudata where the vessel elements are quite long (ancestral trait) whereas perforation plates are specialized - mixed or simple.

Analysis of general vessel morphology: perforation plates, pits, vessel length and width are invaluable for better understanding phylogenetic relationships and evolution of the plant hydraulic system [14]. There are studies that show high correlation between vessel members' length and diameter [33] while others report that there is no relationship between those traits [34]. In this paper no correlations have been found between the dimensions of Magnolia vessel elements. Vessel diameter is correlated with environmental conditions and also with the stem age and size $[14,35]$ and vessel length is related to cambial initial cell length [36]. In roots the vessel elements are wider in diameter but not always longer than in the stems [37]. Because the magnolias in this research were collected from the areas with similar climate [38], and the material was taken from the same organs - 6-12 years old branches - their general wood architecture as well as vessel cell dimensions were similar.

There is available a very limited set of morphological and anatomical data for mature branches. To make proper taxonomic investigations the knowledge about wood structure and anatomy not only from the main stem but also from other parts of the plant is important. Results from this paper show that using branch material can be quite advantageous and may provide satisfactory, sufficient data for phylogenetic and taxonomic analysis.

In conclusion, this paper confirmed that wood anatomy is a great source of traits that may be used in the studies of evolutionary relationships within flowering plants. Thorough phenotypic analysis of these plants, which represent the ancestral lines, is very important for better understanding the evolutionary trends and different opportunities for development. Those studies show that within Magnolia genus phylogenetic progressions are already visible. Wood modifications, similar to those observed in evolution of younger lineages of flowering plants, like shortening of cambial cells and vessel members or progression from scalariform to simple perforation plate, make this group quite advanced, but also provide a good example of convergent evolution. 


\section{Acknowledgments}

This work was supported by the University of Wrocław (grant No. 1068/S/ $\mathrm{IBE} / 13)$.

\section{Competing interests}

No competing interests have been declared.

\section{References}

1. Soltis PS, Soltis DE. The origin and diversification of angiosperms. Am J Bot. 2004;91(10):1614-1626. http://dx.doi.org/10.3732/ajb.91.10.1614

2. Canright JE. The comparative morphology and relationships of the Magnoliaceae. I. trends of specialization in the stamens. Am J Bot. 1952;39(7):484. http://dx.doi.org/10.2307/2438333

3. Canright JE. The comparative morphology and relationships of the Magnoliaceae. II. The significance of the pollen. Phytomorphology. 1953;3:355-365

4. Zagórska-Marek B. O przyczynach zmienności planu budowy kwiatu. Postępy Biol. Komórki. 27(1):97-109.

5. Zagórska-Marek B. Magnolia flower - the living crystal. Magnolia. 2011;89:11-21.

6. Nooteboom HP. Notes on Magnoliaceae, with a revision of Pachylarnax and Elmerrillia and the Malesian species of Manglietia and Michelia. Blumea. 1985;31:65-121.

7. Figlar RB, Nooteboom HP. Notes on Magnoliaceae IV. Blumea. 2004;49(1):87-100. http://dx.doi.org/10.3767/000651904X486214

8. Kim S, Park CW, Kim YD, Suh Y. Phylogenetic relationships in family Magnoliaceae inferred from $n d h F$ sequences. Am J Bot. 2001;88(4):717-728

9. Mathews S, Donoghue MJ. Basal angiosperm phylogeny inferred from duplicate phytochromes $a$ and $c$. Int J Plant Sci. 2000;161(6 suppl):S41S55. http://dx.doi.org/10.1086/317582

10. Demura T, Fukuda H. Transcriptional regulation in wood formation. Trends Plant Sci. 2007;12(2):64-70. http://dx.doi.org/10.1016/j. tplants.2006.12.006

11. Yata S, Itoh T, Kishima T. Formation of perforation plates and bordered pits in differentiating vessel elements. Wood Res. 1970;50:1-11.

12. Plomion C, Leprovost G, Stokes A. Wood formation in trees. Plant Physiol. 2001;127(4):1513-1523. http://dx.doi.org/10.1104/pp.010816

13. Carlquist $\mathrm{S}$. Xylem heterochrony: an unappreciated key to angiosperm origin and diversifications. Bot J Linn Soc. 2009;161(1):26-65. http:// dx.doi.org/10.1111/j.1095-8339.2009.00991.x

14. Herendeen PS, Wheeler EA, Baas P. Angiosperm wood evolution and the potential contribution of paleontological data. Bot Rev. 1999;65(3):278-300. http://dx.doi.org/10.1007/BF02857632

15. Carlquist S. Lateral wall pitting of vessels. In: Timell TE, editor. Comparative wood anatomy systematic, ecological, and evolutionary aspects of dicotyledon wood. Berlin: Springer Berlin Heidelberg; 2001. p. $74-82$.

16. Canright J. The comparative morphology and relationships of the Magnoliaceae. IV. Wood and nodal anatomy. J Arnold Arbor. 1955;36:119-143.

17. Kubitzki K, Rohwer J, Bittrich V. Flowering plants - Dicotyledons. Magnoliid, Hamamelid and Caryophyllid families. In: Kadereit JW, editor. Families and genera of vascular plants. Berlin: Springer; 1993. p. 391-402. (vol 2).

18. Baas P, Liang CB, Wheeler EA, Shuming W. Wood anatomy of trees and shrubs from China. VI. Magnoliaceae. IAWA J. 1993;14(4):391-412. http://dx.doi.org/10.1163/22941932-90000594
19. Peel MC, Finlayson BL, McMahon TA. Updated world map of the Köppen-Geiger climate classification. Hydrol Earth Syst Sci. 2007;11(5):1633-1644. http://dx.doi.org/10.5194/hess-11-1633-2007

20. Johansen DA. Plant microtechnique. New York, NY: McGraw-Hill Book Co.; 1940.

21. Gerlach D. Zarys mikrotechniki botanicznej. Warsaw: PWRiL; 1972.

22. R Development Core Team. R: a language and environment for statistical computing. Vienna: R Foundation for Statistical Computing; 2011.

23. Frodin D, Govaerts R. World checklist and bibliography of Magnoliaceae. Kew: Royal Botanic Gardens; 1996.

24. Carlquist S. Ecological strategies of xylem evolution. Berkeley, CA: University of California Press; 1975.

25. InsideWood [Internet]. 2004 [cited 2014 Oct 2]; Available from: http:// insidewood.lib.ncsu.edu/search

26. Wheeler EA. InsideWood - a web resource for hardwood anatomy. IAWA J. 2011;32(2):199-211.

27. Meylan BA, Butterfield BG. Occurrence of simple, multiple, and combination perforation plates in the vessels of New Zealand woods. N Z J Bot. 1975;13(1):1-18. http://dx.doi.org/10.1080/002 8825X.1975.10428879

28. Carlquist SJ. Scalariform perforation plate variants. In: Timell TE, editor. Comparative wood anatomy: systematic, ecological, and evolutionary aspects of dicotyledon wood. Berlin: Springer; 1988. p. 68-72.

29. Azuma H, Garcia-Franco JG, Rico-Gray V, Thien LB. Molecular phylogeny of the Magnoliaceae: the biogeography of tropical and temperate disjunctions. Am J Bot. 2001;88(12):2275. http://dx.doi. org/10.2307/3558389

30. Nie ZL, Wen J, Azuma H, Qiu YL, Sun H, Meng Y, et al. Phylogenetic and biogeographic complexity of Magnoliaceae in the Northern Hemisphere inferred from three nuclear data sets. Mol Phylogenet Evol. 2008;48(3):1027-1040. http://dx.doi.org/10.1016/j.ympev.2008.06.004

31. Frost FH. Specialization in secondary xylem of dicotyledons. II. Evolution of end wall of vessel segment. Bot Gaz. 1930;90(2):198. http://dx.doi.org/10.1086/334094

32. Takahashi A. Wood anatomical report of some Magnoliaceae from Borneo. J Phytogeogr Taxon. 1989;37:93-100.

33. Lens F, Sperry JS, Christman MA, Choat B, Rabaey D, Jansen S. Testing hypotheses that link wood anatomy to cavitation resistance and hydraulic conductivity in the genus Acer. New Phytol. 2011;190(3):709723. http://dx.doi.org/10.1111/j.1469-8137.2010.03518.x

34. Wheeler JK, Sperry JS, Hacke UG, Hoang N. Inter-vessel pitting and cavitation in woody Rosaceae and other vesselled plants: a basis for a safety versus efficiency trade-off in xylem transport. Plant Cell Environ. 2005;28(6):800-812. http://dx.doi. org/10.1111/j.1365-3040.2005.01330.x

35. Zhang S, Baas P. Wood anatomy of trees and shrubs from China. III. Rosaceae. IAWA J. 1992;13:21-91.

36. Kitin P. Variations in the lengths of fusiform cambial cells and vessel elements in Kalopanax pictus. Ann Bot. 1999;84(5):621-632. http:// dx.doi.org/10.1006/anbo.1999.0957

37. Jacobsen AL, Pratt RB, Tobin MF, Hacke UG, Ewers FW. A global analysis of xylem vessel length in woody plants. Am J Bot. 2012;99(10):1583-1591. http://dx.doi.org/10.3732/ajb.1200140

38. Ziernicka-Wojtaszek A. Weryfikacja rolniczo-klimatycznych regionalizacji Polski w świetle współczesnych zmian klimatu. Acta Agrophys. 2009;13(3):803-812. 